総説

\title{
栄養による脳卒中の予防
}

\author{
家 森 幸 男 \\ 島根医科大学病理学教室
}

\section{Dietary Prevention of Hypertension and Stroke}

Yukio Yamori, M. D.

Department of Pathology, Shimane Medical University

はじめに

アメリカにおける大規模な軽症高血圧患者の降圧治療に関する最近の研究の結果, 軽症高血王でも治療群の ほうが死亡率も心血管合併症の発症も有意に少なかったという報告1)がなされて以来，軽症高血压を楽物治療 すべきかどうか，そしてする場合はどのような時期にいかなる治療を行うのが適切かが大きな問題となってい る。

この際，注目しなければならないのは，日米の大きな環境因子，特に栄養条件の差である。これまでの我々

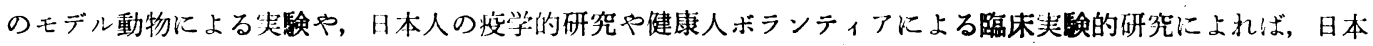
人の食生活は高血圧の遗伝絜因の発現を促進し，欧米人のそれはむしろ抑制的に働くため，日朴人の高血圧の 場合，特に軽症高血圧は栄菱条件によってコントロールしらる可能性が大きく，脳卒中も食事によって予防で きると考えられる。以下に最近まで得られた头臨モデルによる知見と，それを支持する疫学的，臨休夫験的観 察をまとめて述べる。

\section{脸卒中モデルの発展とその成因}

高血圧自然発症ラット $(\mathrm{SHR}, 1963)^{1)}$ をはじめとして脳卒中易発症 SHR (SHRSP*1, 1974) ${ }^{3) 4}$ ), 動脈硬

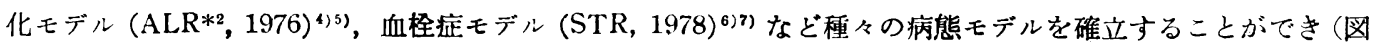

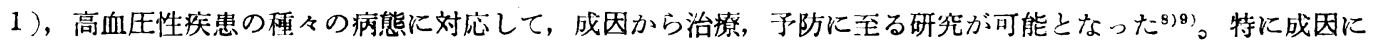

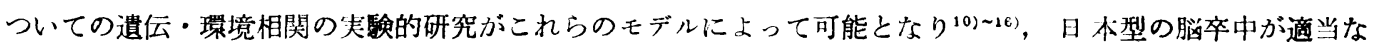
栄養揕取により予防されることが明らかになった ${ }^{8) \sim 10) 17) 。 ~}$

SHR の中で脳卒中を発症したラットの子孫のみを残して選択交配を行い確立したSHRSPは, 脳血管障害を 100\%近く自然発症するニニークな系統として脳卒中の発症機序から予防の研究に役立ってきた 年期より発症する高血圧が，この睬卒中の最大のリスクファクターになっており, 高血圧の予防的治療で脳卒

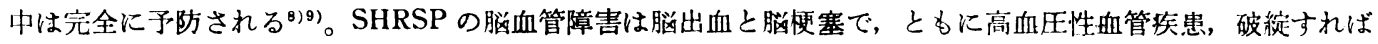
脳出血，血栓を伴い，閉塞すれば脳梗塞となることが明らかになっている5) 10)。

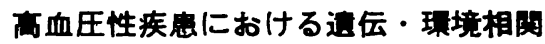

脳卒中の最大のリスクファクターは高血圧である。高血圧に影響する環境因子として,ストレス ${ }^{(8)}$ と食塩 $^{(9) 20)}$ *1: stroke-prone spontaneously hypertensive rats

$*^{2}:$ arteriolipidosis-prone rats 


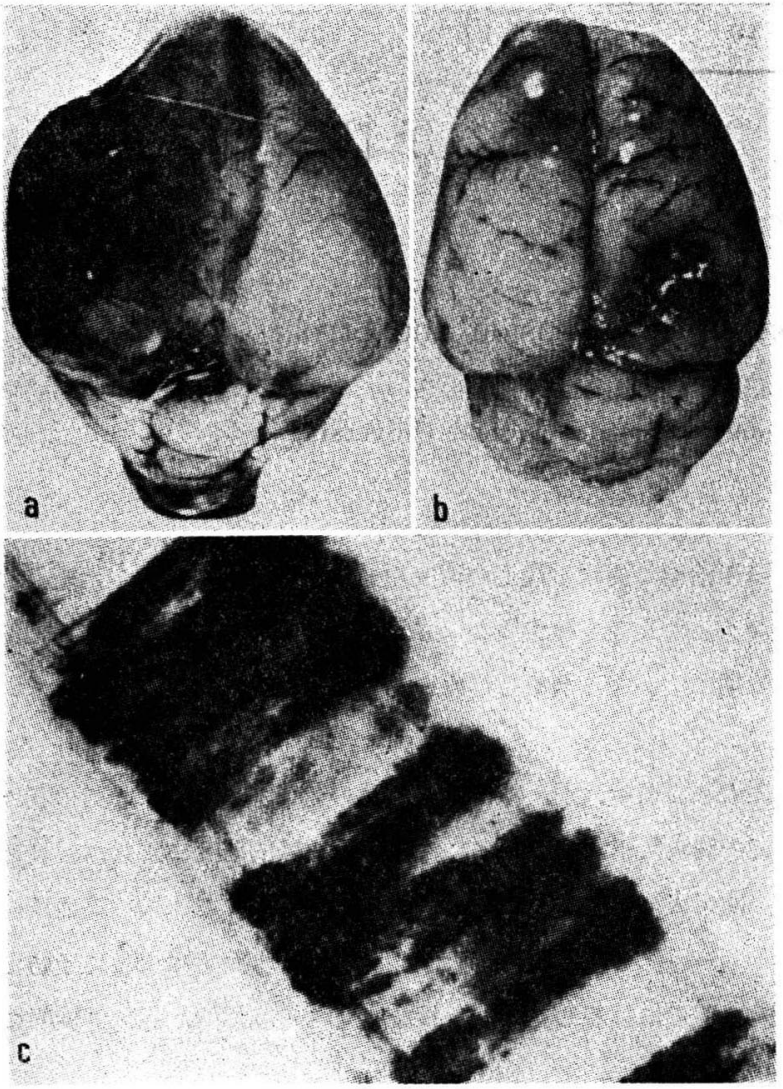

図 1 SHRSP に打ける脳出血 $(\mathrm{a})$ と脳梗塞 ( $\mathrm{b}$ )

注）このような脳血管障害のため，雄，雙それぞれ平均 9,13 カ月の寿命で死亡する。

動脈便化のモデル：動脈脂肪沈着易発症ラット(ALR)。高 脂肪コレステロール食の負荷で $1 \sim 3$ 週間で強い反応性高脂血 症を発症するととも晹間膜動脈 (c) や脳底部動脈にリング 状脂肪沈着を生ずる。

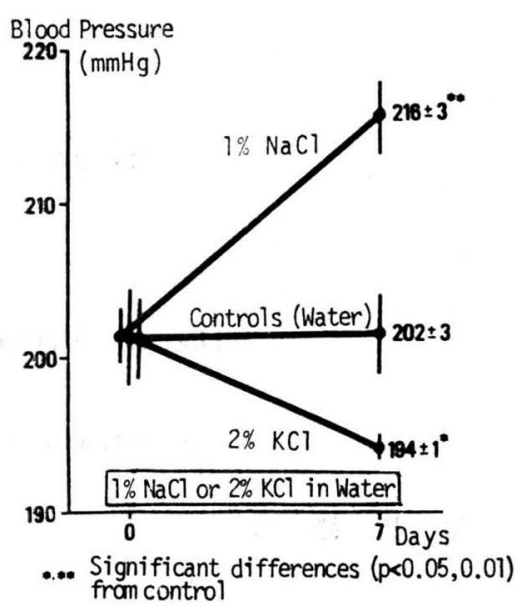

図 2 SHRSP そおける $\mathrm{Na}$ と K 掑 取の効果

注) 食塩負荷 ( $1 \% \mathrm{NaCl}$ 含有领料水) は血圧を短期間に上身させるが，K 負荷 $(2 \% \mathrm{KCl}$ 含有飲料水) はむし ろ血圧を抑制する。

をはじめとする食䭒性因子がある。最 近のSHRSP の研究で明らかになった のは, 高血圧性疾患と食塩, 脂質およ びたん白質椇取など食䬺ないし栄養と の関係である ${ }^{17)}$ 。

1. 食塩, 特に $\mathrm{Na} / \mathrm{K}$ 比と高血圧・

\section{脳卒中}

SHR を普通食で飼育すると，190〜 $200 \mathrm{mmHg}$ の高血圧になり，1\%の食塩水を与えると高血压はより早く発症し，また $240 \mathrm{mmHg}$ る重症高 血圧になる ${ }^{17) 19}$ 。しかし，減塩食で飼育しても，170 mmHg 程度の高血圧にはなるので, 食塩負荷は高血圧を 重症化させるといえる(7)19j。この際さらに，素因によってその年王反応が異なる。たとえば，1\%食塩水を10 週間与えても，正常血圧のWKY（W istar-Kyoto rats)では䒜压はわずかであり，SHR ではその年圧がやや 大きいが SHRSP ではさらに界圧が著しい20)。この際, SHRSP では 3 カ月以内にほとんぞ全例脳卒中を発症 する。すなわち，脳卒中素因が強いほど食塩の影響も大きいといえる。さらに実験的にもカリウム $(\mathrm{K})$ がナ トリウム (Na) のこのような增悪効果に拈抗することす証明された (図 2$)^{17)}$ 。

SHR やSHRSP の研究によって, 高血圧の場合は, 上り細胞内に Na が貯留しやすい傾向にあることが 最近明らかになり, 細胞レベルでの食塩感受性のメカニズムと高血圧の遺伝的成因論の研究に大きな展開が起 こりつつある (図 3$)^{21}$ 。疫学的には 1,200 人の農村に拈いて尿中の $\mathrm{Na} / \mathrm{K}$ 比と血圧のレベルおよび高血压の 発症頻度が正相関することを証明した（図 4 )。すなわち， $\mathrm{Na} / \mathrm{K}$ 比が日本人の平均に近い 6 以上では, $30 \%$ 以 上が高血圧で，逆にこれが欧米人のレへルの 3 以下では15\%以下にしか高血圧の発症がみられず，日本と欧米 


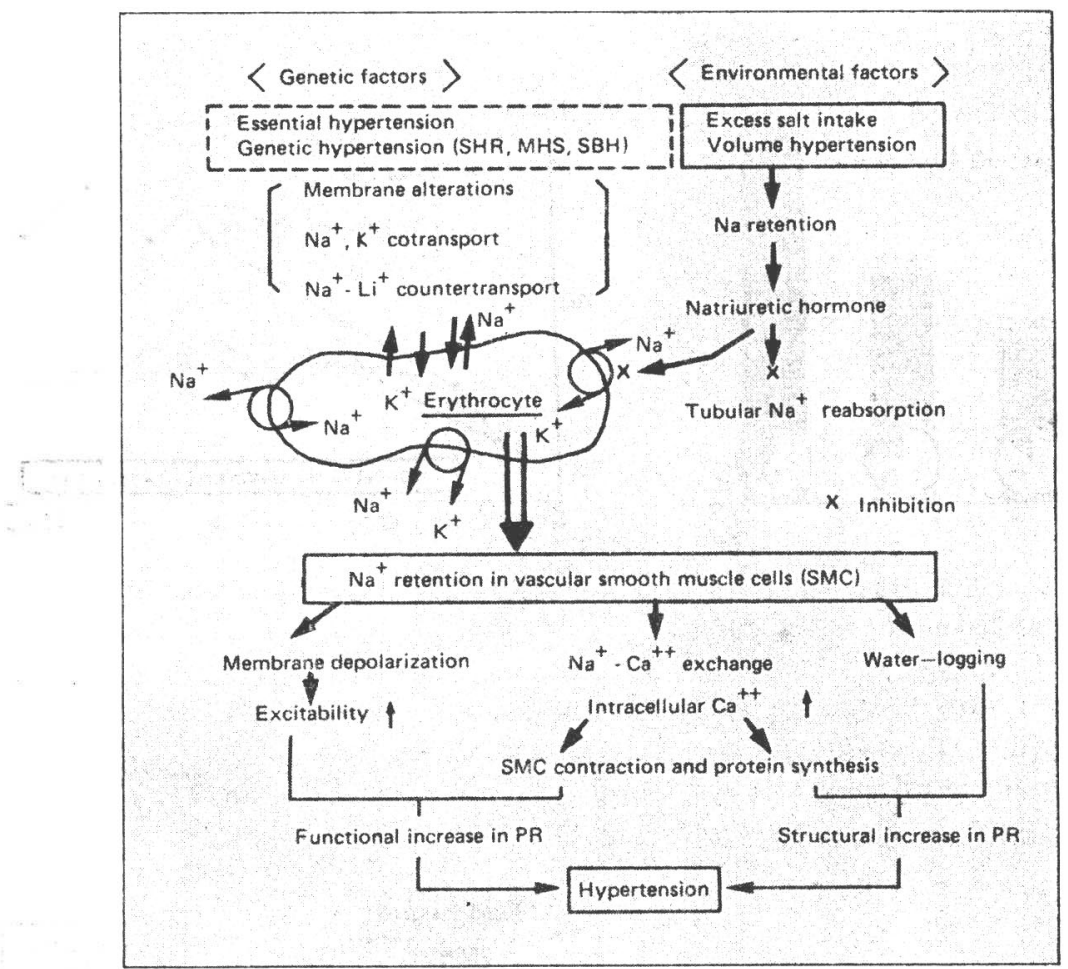

四 3 遺伝的高血圧症における細胞レペルでの高血圧発症機序, 特に食塩 $(\mathrm{Na})$ の影響に関する遺伝環 境相関に関する考察（家森，1981）

注）モデル動物や人で得た結果を基に高血圧の発症機序を考察すると，最初， Na イオン透過性に対し 遺伝的な異常があるため，細胞内への Na 販留傾向が生じ，その上に食塩を過剩摄取すると，細胞 内への $\mathrm{Na}$ の貯留が著しくなる。その結果, 体内の $\mathrm{Na}$ 保持量が多くなり, 腎からの $\mathrm{Na}$ 排泄を促 進するため, いわゆる natriuretic hormone の分泌が高まる。このホルモンは Na, K-ATPase 活 性を阻害し，腎での Na 再吸収を㧕制する。しかし，これは腎のみに作用するのではなく，全身に作 用するため，血管平滑筋細胞にも影響を及ぼす。それゆ光，細胞内への $\mathrm{Na}$ の貯留がさらに増大する。 平滑筋細胞内の $\mathrm{Na}$ イオンが増加すると, 細胞内水分含量が平衡して増加し, 末梢抵抗が上䒜する。 また，Na イオンと Ca イオンの相互作用の結果，血管の収縮性や増殖性が高まる。高血圧は以上の 経過をたどって成立し，固定すると考察される。

における高血圧性疾患の発症頻度の差が食事の $\mathrm{Na} / \mathrm{K}$ 比の差によっても証明しらる。また，健康人ボランテ ィアの臨床栄養実験により，高血圧の家族歴を有する者では，減塩食 $(6 \mathrm{~g} /$ 日) から食塩負荷 (25g/日)した場 合の年王が家族歴のない者に比べて明らかに大きいことを証明した。また，Kの負荷により尿中 $\mathrm{Na} / \mathrm{K}$ 比の低 下とともに血圧が低下することも証明した。すなわち，モデル動物の実験によって示されたごとく，ヒトにお いても $\mathrm{Na}$ 負荷による昇圧は遺伝素因が極めて重要で, 食事の $\mathrm{Na} / \mathrm{K}$ 比により高血圧の程度および発症率が 影響され，この低下，すなわち食事中の $\mathrm{Na}$ の減少と $\mathrm{K}$ の積極的増加が，高血圧性疾患の予防に重要であ ることが示された。

\section{2. 脂肪摂取之高血圧性疾患}

日米間に脳卒中の頻度の差があり，日本では脳卒中が多く，しかす血清コレステロールの低い地域ほどそれ が多発している事実は広く認められるよらになった。SHRSP を，20\%脂肪と種々の量のコレステロールを含 


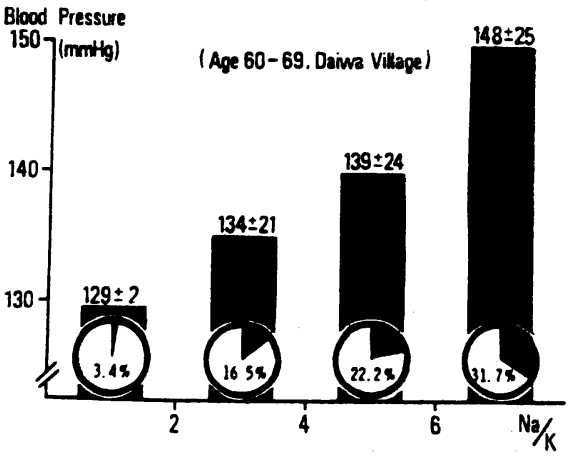

図 4 涾中 $\mathrm{Na} / \mathrm{K}$ 比と収䧽期ならびに高血 圧症（収縮期 $160 \mathrm{mmHg}$ ，扗張期95 $\mathrm{mmHg}$ 以上）の割合

注）成人検搒人口 1,200 人の一山村（島根県 大和村）で60歳代では尿中 $\mathrm{Na} / \mathrm{K}$ 比が高 くなるほど血圧の平均值も有意に高くな りまた，高血圧患者の割合も有意に多 くなる。

さ脂肪食で飼育した場合，重症高血压の発症。 は抑制され（図 5 ），高血圧に基づく動脈装 死血栓性脳卒中は減少する ${ }^{917)}$ 。暞々の脂肪 で SHRSP を飼育すると, 脂肪の種類によ って高血圧の㧕制のされうは異なること，概 してアテローム動脈硬化を促進しやすい条件 ほど，高血圧は㧕制されていることが証明さ れた (図6 6$)^{17) 。 ~}$

しかし，この条作を长期間続けると腷底湖 の動脈などに脂肪汇等を俳うアテローム硬化 性病変を起こす。したがって，高コレステロ 一ル血症を伴うと日本型の脸卒中は減少する が，冠動脈のアテローム硬化による心胼梗塞 ないし中大動脈の硬化から血栓ないし塞栓㾋

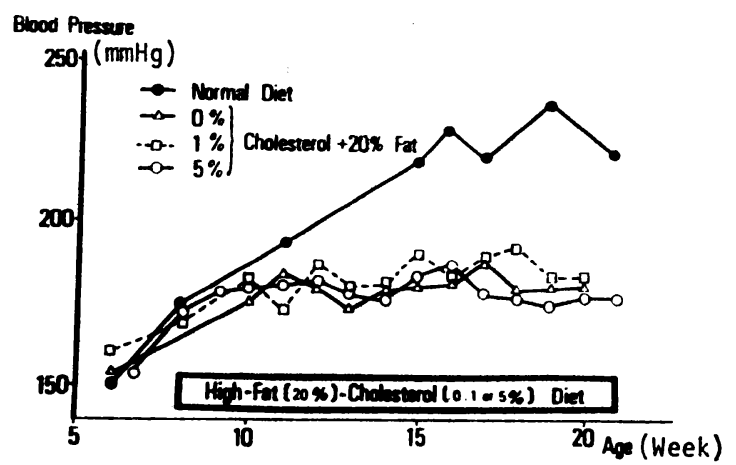

図 5 SHRSP における高脂肪コレステロール食の血圧に及 ぼす影響

注 種々のコレステロールを合む $20 \%$ 牛脂食で飼育すると SHRSP の血王上年は抑制され，重症高血王による動脈 壊死性脸卒中は減少する。

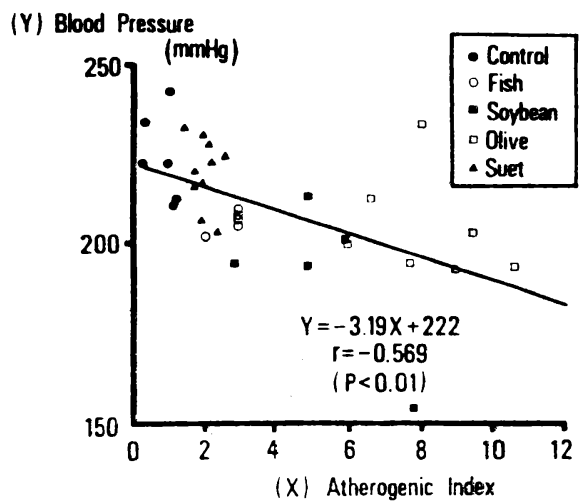

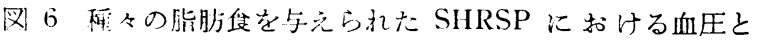
アテローム破化指数の閔係

注!

アテローム属＝総コレステロールーHDL コレステロール 化指数 $X)=$ 総コレステロール

$\mathrm{X}$ と血压（Y）は有意の逆相関があり，アテローム硬化 を促進する食能结ど重症高血圧を㧕制する傾问がある。

による脳梗塞を起こすことになる。このことは，脂肪摄取の多い欧米で心筋柀塞が多く，この摄取の少ない日 本で脳卒中が多いという疫的事尖とよく一致する。

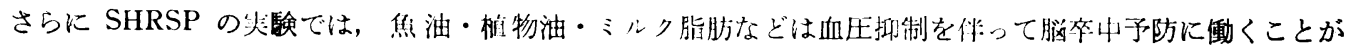
証明され，また，日本人の潐村・農村の住式およびアメリカ人の血清脂肪酸の比較により, 以上の動物実験を 支持する知見が得られた。すなわち，脂肪掫取不足の日本農村では脳卒中が多く，それが過剩のアメリカでは 心㬳梗塞が多く, 魚油に由来する多価不飽和脂肪酸を比較的多くとっている日本の漁村では, 脑卒中, 心㬳梗 
塞ともに少ないことが証明された。

\section{たん白算・アミノ酸による脳卒中予防}

高たん白食に脳卒中予防効果のあることが， SHRSP ではじめて実験的に証明された4)8) 10) 17)。すなわち，低たん白食で $1 \%$ 食塩水を与兄 て飼育すると, 短期間で重症高血圧になり, 100 \%脳卒中を発症する。低たん白食だけです75\% 脳卒中になる。魚のたん白を多く含む高たん白 食では，たとえ $1 \%$ 食塩水を与えても脳卒中は 10\%と少なく，食塩がなければ高血圧も抑えら れ脳卒中はほとんど発症しない(図 7$)^{17) 。 こ ~}$ のような SHRSP にたん白食を与えると脳卒 中の発症が明らかに少なくなるといら観察か ら，高たん白食の脳卒中予防機序について分析

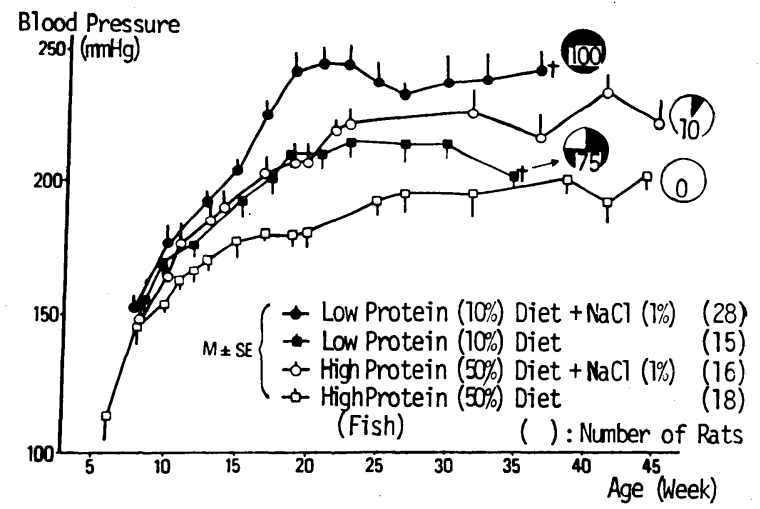

図 7 SHRSP に打ける食塩とたん白質摂取量の高血圧と 脳卒中の頻度に及ぼす影響

注）食塩過剩摄取（1％食塩水飲用）は高血圧症を增悪 させ, 脳卒中を増加させるが, 魚粉たん白食は重症高 血圧を抑制し，食塩の高血圧増悪効果を弱め，脳卒中 の発症率を下げる。
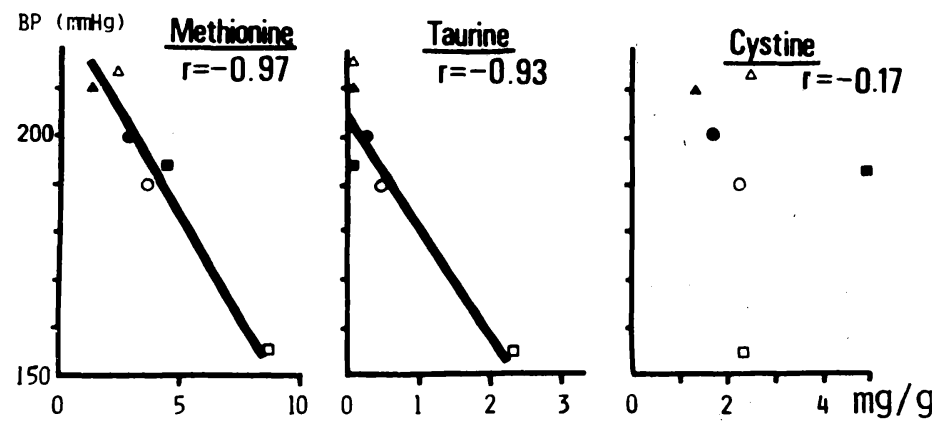

- Joponese (SP) Dlet - LOW (10x) Protein Diet - Soybean Prote in Dlet - Amerlcon (NIH) Diet $\Delta$ Chemicolly-defined Dlet ofIsh Frotein Dlet

図 8 SHRSP の血圧と食慨中の各種フミノ酸量の関係

注） 飼料からのメチオニンやタウリンの摄取量（体重当たりのフミノ酸量）が多いほど血圧は低い（各 点は10匹以上の SHRSP の血圧の平均值を表す)。

が進められてきた。魚粉たん白はよく血圧を抑えるが，大豆たん白は血圧には大きな影響のないこともわかっ

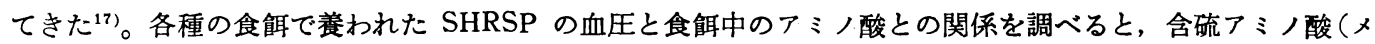

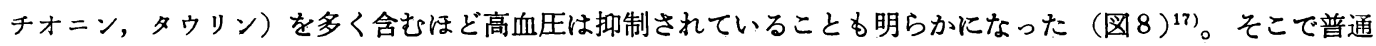

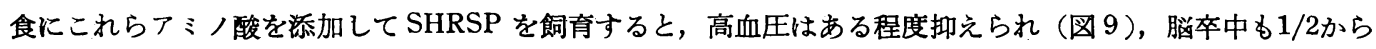
$1 / 3$ に減少した ${ }^{22)}$ 。魚たん白は重症高血圧を抑制するが，魚たん白の構成アミノ酸のらち含硫アミノ酸（タウ リン，メチオニン）には降圧効果がありここれが中枢神経性降圧であることをこれらのフミノ酸の脳室内微量 注入により証明した（図10)。最近チロシンにも降圧効果があり, 脳室内钽量投与で降圧がみられ, その際ノル エピネフリンは增加しなかったが, その代謝産物であるMOPEG(4-hydroxy-3-methoxyphenylethylglycol) が脸内で增加していたため，この降圧機序は中权性の $\alpha$ 受容体を介していると考えられた。さらにReisらは， 
グルタミン酸が調殴神経伝達物質として

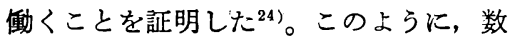
種の有効なアミノ酸は高血圧の㧕制を介 して脳卒中予防に役立つようである。こ の他のたん白質の効果として，尿素の増 加とともに尿中への $\mathrm{Na}$ の排泄を増やす ことも明らかになり ${ }^{25) 26)}$, これが食塩過 剩摄取の悪効果を打ち消すと考えられる。 最近の研究では, たん白の代わりに尿素 を加えた飼料でSHRSPを飼育しても高 血圧の抑制がみられ，この際尿への $\mathrm{Na}$ 排泄も多いことがわかった。

一方，大豆たん白には，降圧効果はな いが，脳卒中の発症は抑制される。この 㻮，動脈は大動脈も脳動脈もともによ

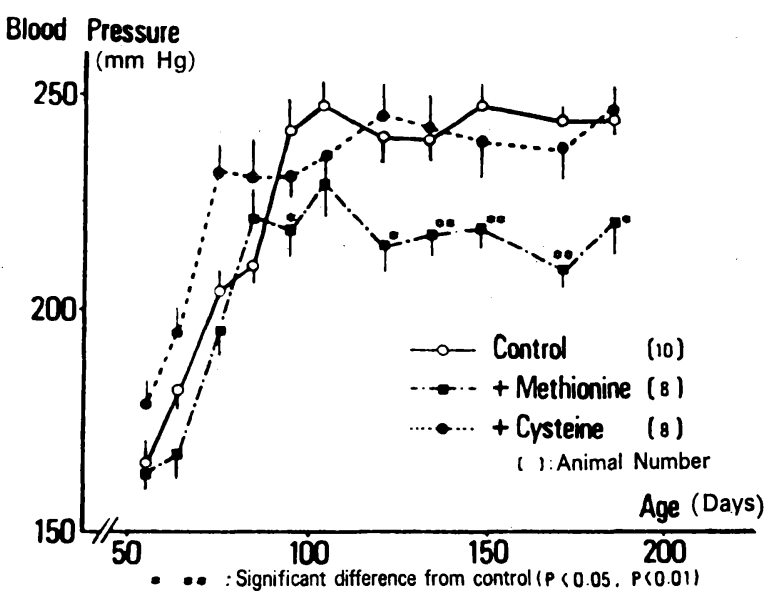

図 9 メチオニン, システインの血压に及ぼす影響

注）食慨にメチオニン $(1.5 \%)$, システイン $(1.2 \%$ ， ィチ オニンと等モル）を混ぜて与えるとメチオニン群の高血压 は抑制され，脳卒中は減少したが，システィン群では効果 がなかった。

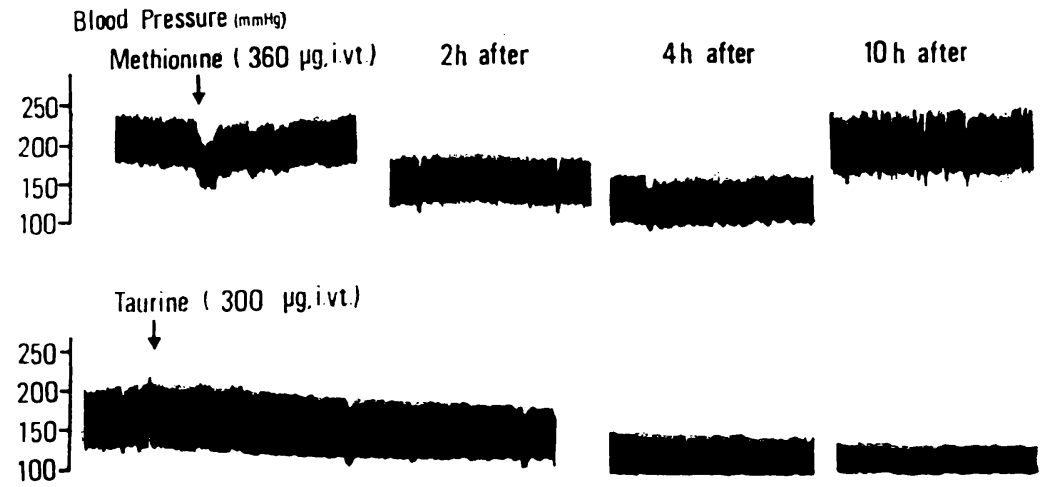

図 10 メチオニン, タウリンの脳室内投与による SHRSP の血圧への影響

注）タウリンでは降压効果はすぐみられたが，メチオニンの場合， $2 〜 4$ 時間後に有意の降压がみられ た。

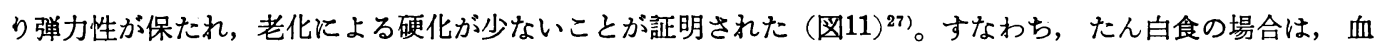
王，Na ハラランス，血管壁に対する作用を介して高血王性疾患を予防するわけである ${ }^{27) 。 ~}$

疫学的には，動物性たん白質の㩒取はタウリンなど含硫アミノ酸に由来する尿中の硫酸基(S)の測定により， また,たん白質摄取総量は尿中の尿素窒素 $(\mathrm{N})$ で測定しうることを確かめ ${ }^{28)}$ ，これを漁村と農村に応用し,脳卒 中の少ない漁村では，動物性たん白質の摄取が脳卒中の多い農村に比べて明らかに多く，また，一集団1,120 人の尿中の $\mathrm{S} / \mathrm{N}$ 比が血圧と逆相関することをはじめて証明し（図12），動物性たん白質，殊に含硫了ミノ酸 の摄取が多いほど人でも高血圧の程度が低く，そのような集団では脳卒中も少ないことが確かめられた また，健康人ボランティアによる臨床栄養実験により，高たん白食の負荷（動物性たん白質 $110 \mathrm{~g} /$ 日）が， 高食塩負荷（20 g/日）による界王を抑制し，その際，尿中への Na 排泄が促進されていることを証明した ${ }^{211}$ 。 


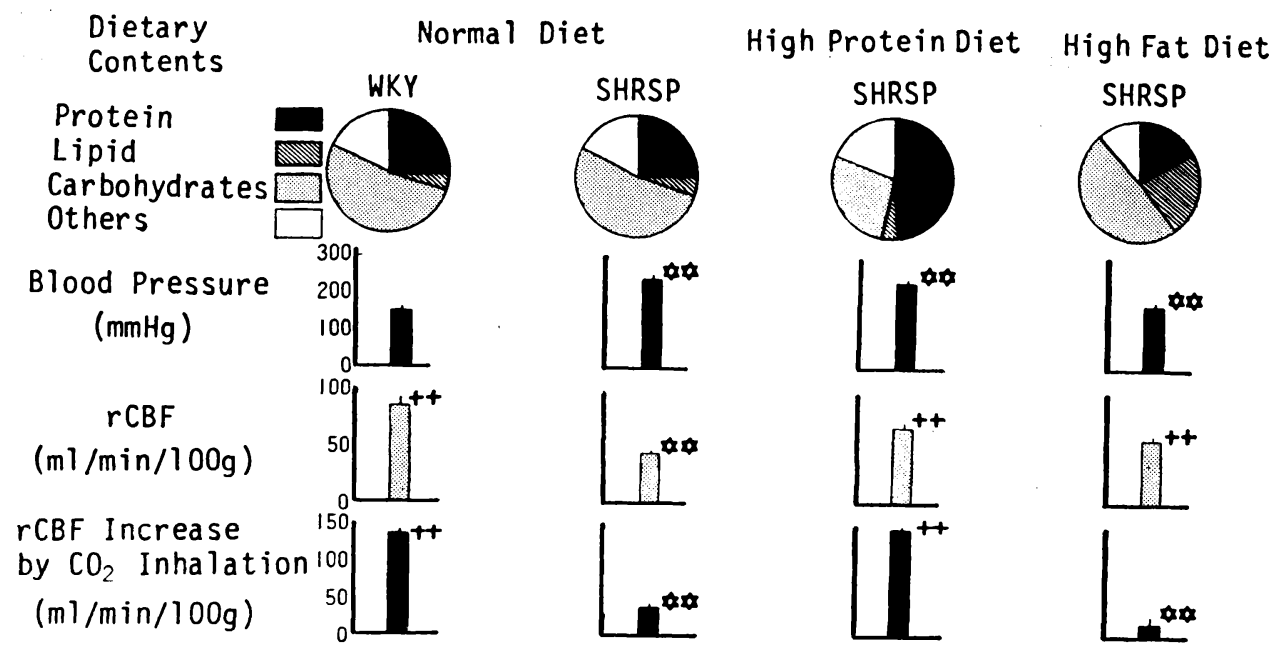

a Significant difference from Wistar-Kyoto rats on a normal diet $(p<0.01)$ ++ ; Significant difference from SHRSP on a normal diet $(p<0.05,0.01)$

困 11 SHRSP 飞打ける高たん白（大豆）食と高脂肪食の $\mathrm{CO}_{2}$ 反応性脳血流増加に及洔す影響

注）高たん白食で飼育された SHRSP では普通食で飼育された正常血圧ラットと同じ程度に反応性が良 好に保たれていたが，普通食や高脂肪食で飼育された SHRSP では反応性は著しく低下していた，

以上のごとく，たん白質の摄取は，SH RSPのみならず人においても，高血圧性疾 患を抑制し，その機序の一部が明らかにな った。

おわりに

SHR から種々の循環器疾患のモデル動 物が発展し，高血圧に基づく疾患の遺伝素 因とメカニズム，殊に発症における遺伝・ 環境相関が分析され，これによって脳卒中 をはじめ高血圧性疾患の発症することが極 めて明嘹に示された。このことは，遺伝素 因があれば，それを早期に検出できる可能 性があり，素因がある場合は環境因子を食 塩制限，たん白質摄取などでコントロール

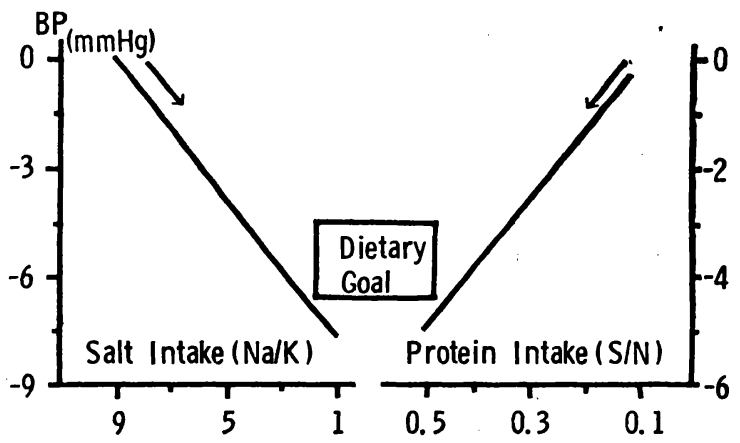

図 12 一山村 1,120 人の成人に括ける尿中の $\mathrm{Na} / \mathrm{K}$ 比および $\mathrm{S} / \mathrm{N}$ 比と血圧との関係

注） $\mathrm{Na} / \mathrm{K}$ 比が低いほど, また， $\mathrm{S} / \mathrm{N}$ 比（硫酸量の窒素全 体に対する割合，すなわち，動物性たん白質の摄取量） が大きいほど血圧の低いことが一集団内で示された。こ らした集団では， $\mathrm{Na} / \mathrm{K}$ 比を小さく， S/N 比を大きくす るような食事目標が血圧を低下させ，脳卒中を予防する と推論できる。

すれば高血圧性疾患は予防できることが実験的に証明された ${ }^{30)}$ 。

さらに以上の実験的・疫学的, および臨床栄養学的研究の結果は，たん白質および脂肪摄取が少なく，食事 の $\mathrm{Na} / \mathrm{K}$ 比が極めて高い日本の伝統的栄養条件は, いずれも高血圧の遺伝素因を有する場合この発現を促進 していると考えられ，それに対したん白質・脂肪摄取が多く， Na/K 比が比較的低い欧米の栄養条件は，高血 印の遗伝素因の発現を㧕制していると推定される。 
したがって, 同じく軽症高血王であっても日本人の場合は, 食事の改善でコントロールしらる可能性が欧米 人に比べてょり大きいと結論しらる。したがって，これらの事実は，日本人の高血圧対策にはまず食事条件の. 改善が極めて重要であることを強く支持している。

\section{文献}

1) Hypertension Detection and Follow-up Program Cooperative Group: JAMA, 242, 2562 2577 (1979)

2) Okamoto, K. and Aoki, K.: Jpn. Circul. J., 27, 282 293 (1963)

3) Okamoto, K., Yamori, Y. and Nagaoka, A. :Circul. Res., 34, 35 (suppl. 1), 143 153 (1974)

4) Yamori, Y., Horie, R., Akiguchi, I., Ohtaka, M., Nara, Y. and Fukase, M.: Clin. Exp. Pharmacol. Physiol. (suppl. 3), 199 203 (1976)

5) Yamori, Y.:Jpn. Heart J., 18, 602 603 (1977)

6) Yamori, Y., Horie, R., Ohtaka, M., Nara, Y. and Ikeda, K.: Jpn. Circul. J., 42, 1151 1159 (1978)

7) Yamori, Y., Ohta, K., Horie, R., Ohtaka, M., Nara, Y. and Ooshima, A.: Jpn. Heart J., 20. (suppl. 1), 343 345 (1979)

8) Yamori, Y., Horie, R., Akiguchi, I., Nara, Y., Ohtaka, M. and Fukase, M.: Progress in Brain Research 47, “Hypertension and Brain Mechanisms", pp. 219 234 (1977) Elsevier, Amsterdam

9) Yamori, Y., Horie, R., Handa, H., Ohtaka, M., Nara, Y. and Fukase, M.: Spontaneous Hypertension; Its Pathogenesis and Complications, pp. 269 278 (1977) DHEW Publication No. (NIH) 77-1179

10) Yamori, Y.: Gene-Environment Interaction in Common Diseases, pp. 151 154 (1977) Univ. of Tokyo Press

11) Tanase, H., Suzuki, Y., Ooshima, A., Yamori, Y. and Okamoto, K.: Jpn. Circul. J. 34, 1197〜 $1212(1970)$

12) Tanase, H., Suzuki, Y., Ooshima, A., Yamori, Y. and Okamoto, K.: Spontaneous Hypertension, pp. 9〜12 (1972) Springer-Igaku Shoin, New York, Berlin, Tokyo

13) Tanase, H., Suzuki, Y. and Yamori, Y.: Prophylactic Approach to Hypertensive Diseases, pp. 115 120 (1979) Raven Press, New York

14) Yamori, Y.: Jpn. Circul. J., 41, 259 266 (1977)

15) Yamori, Y., Ikeda, K., Kihara, M., Horie, R., Nara, Y. and Oosima, A.: Jpn. Heart J., 21, 558 (1980)

16) Yamori, Y., Ikeda, K., Ooshima, A. and Fukase, M.: Prophylactic Approach to Hypertensive Diseases, pp. 121 125 (1979) Raven Press, New York

17) Yamori, Y.: New Trends in Arterial Hypertension, INSERM Symposium No. 17, pp. 305 320 (1981) Elsevier/North-Holland Biomedical Press, Amsterdam

18) Yamori, Y., Matsumoto, M., Yamabe, H. and Okamoto, K.:Jpn. Circul. J., 33, 399 409 (1969)

19) Aoki, A., Yamori, Y., Ooshima, A. and Okamoto, K.: Jpn. Circul. J., 36, 539 545 (1972.)

20) Yamori, Y., Nara, Y., Kihara, M., Horie, R. and Ooshima, A.: Frontiers in Hypertension Research, pp. 46 48 (1981) Springer-Verlag, New York, Heidelberg, Berlin

21) Yamori, Y., Kihara, M., Nara, Y. and Horie, R.: Magnesium, 1, 163 171 (1982)

22) Yamori, Y., Horie, R., Nara, Y., Kihara, M. and Ikeda, K.: Eighth International Congress of Pharmacology, p.234 (1981)

23) Yamori, Y., Fujiwara, M., Horie, R. and Lovenberg, W.:Eur. J. Pharmacol., 68, 201 204 (1980) 
24) Talman, W.T., Perrone, M. H. and Reis, D.J.: Science, 209, 813〜815 (1980)

25) Yamori, Y., Horie, R., Nara, Y., Ikeda, K., Kihara, M., Ooshima, A. and Fukase, M.:Actualités Néphrologiques Flammarion Médicine-Sciences, pp. 49 71 (1980)

26) Yamori, Y., Horie, R., Nara, Y., Ikeda, K., Ohtaka, M., Ooshima, A. and Sasagawa, S.: Jpn. Heart J., 20, 742 (1979)

27) Yamori, Y., Horie, R., Ikeda, K., Nara, Y. and Lovenberg, W.: Prophylactic Approach to Hypertensive Diseases, pp. 497 504 (1979) Raven Press, New York

28) Yamori, Y., Tsunematsu, T., Note, S., Ishikawa, S. and Fukase, M.: Prophylactic Approach to Hypertensive Diseases, pp. 587 593 (1979) Raven Press, New York

29) Yamori, Y., Kihara, M., Nara, Y., Ohtaka, M., Horie, R., Tsunematsu, T. and Note, S:Lancet, i, 1204 (1981)

30) Yamori, Y., Lovenberg, W. and Freis, E.D. eds.: Prophylactic Approach to Hypertensive Diseases (1979) Raven Press, New York 